\title{
Reading Literacy of Students with Intellectual Disabilities at the End of the Systematic Literacy Development Period
}

\author{
Nika Jenko, Mojca L. Lipec Stopar \\ University of Ljubljana, Faculty of Education, Ljubljana, Slovenia
}

Developing reading literacy of students with mild intellectual disabilities (hereinafter ID) is one of the more challenging educational issues. These students are usually enrolled in an adapted program with lower educational standards (hereinafter AP LES), which predicts that by the end of the literacy development period the students will have mastered reading techniques to the point of being able to focus primarily on developing reading comprehension. Throughout this research, we were interested in finding out the degree to which this goal was fulfilled in a group of 61 fifth grade students with ID, enrolled in AP LES, at the end of the systematic literacy development period. Using factor analysis, we studied the characteristics of reading literacy in this group of students. Additionally, we compared the results of students with ID with the norms created for students of typical development at the end of their literacy development period (third grade). We can conclude that reading efficiency of students with ID at the end of the literacy development period is still based on lower level processes (decoding). Reading issues of students with ID are complex in nature and apply to various factors of reading literacy. Taking the students' oral reading accuracy into account, we can reach a conclusion that only a smaller percentage of students is capable of reaching the fundamental goal of reading lessons in the given amount of time. Based on our results we will be able to give suggestions on how to plan future reading lessons in AP LES.

Keywords: reading literacy, literacy development, intellectual disabilities, adapted program with lower educational standards

Correspondence: Nika Jenko, Nika.Jenko@pef.uni-lj.si

Note. The research was presented at The 9th International Conference of the Faculty of Education and Rehabilitation Sciences, University of Zagreb, 2017 


\section{Introduction}

Special needs of students with mild intellectual disabilities (hereinafter ID) in adapted program with lower educational standards (hereinafter AP LES) are the result of their reduced potential in the field of intellectual functioning and adaptive skills (AAIDD ${ }^{1}$ ), which also includes language skills and literacy. These limitations occurred before the age of eighteen, and in the mentioned areas, the achievements of students with mild ID reach approximately two standard deviations below the average. The characteristics and reading issues of students with ID dictate a prolonged process of developing literacy with adapted and simplified learning content and an emphasis on practical communication skills, which also includes reading.

According to the Slovene Curriculum (Poznanovič Jezeršek et al., 2011), the goal of reading lessons at school is to make students achieve reading literacy by the end of compulsory schooling (Pečjak \& Gradišar, 2002). Reading literacy, defined as an "ability to understand and use those written language forms required by society and valued by the individual" (Harris \& Hodges, 1995, p. 211; Mullis et al., 2006) is key to the development of students' potential and their integration into society.

The central criterion of reading literacy is the reader's ability to understand the given text, or reading comprehension. In students with ID, reading comprehension should always be assessed with respect to their cognitive abilities (Conners, 2003).

As cited in Wren (2001), the reading model by Gough and Tunmer (Simple View of Reading) defines reading comprehension as a product of two equally important components; decoding and language comprehension. The model envisages the equalization of language comprehension (measured through listening comprehension) and reading comprehension in successful readers (Hoover \& Gough, 1990). Research (e.g. Levy, 2011) shows that the differences in intellectual abilities condition the differences in reading literacy performance; however, the authors (e.g. Levy, 2011; Verhoeven \& Vermeer, 2006) are not united about its predictive power.

Due to their intellectual disabilities, students with ID have a lower potential for (listening) comprehension of content compared to students of typical development (hereinafter TD), but regardless, we are still interested in whether they are able to fully demonstrate this in reading activities (to be able to reach reading comprehension at the same level as their listening comprehension).

The results of previous research explain the reasons behind reading difficulties of students with ID from two aspects: slower reading literacy development and structurally different literacy development (compared to readers of TD).

\footnotetext{
1 American Association on Intellectual and Developmental Disabilities
} 
The first viewpoint emphasizes slower general cognitive development in students with ID, which is also reflected in the development of reading literacy. The latter is proven by studies that find that students with ID cannot read as well as students of TD of the same age. Their achievements are more comparable to those of younger students (e.g. Conners et al., 1998). This indicates that reading development in students with ID takes place in the same sequence as in children of TD, albeit more slowly. This interpretation is however only partially sufficient. The assumption about the slower reading development in students with ID dictates an extended period of literacy development. However, an overview of previous research (Conners, 2003) shows that despite the prolonged period of literacy development, many students with ID still understand (by listening) more than by reading. The latter is also confirmed by prior research in Slovenia (Lipec Stopar \& Jenko, 2014), which concluded that some older readers with ID (adolescents in transition to lower vocational education) do not achieve their full potential in understanding content simply due to a poor reading technique. At the same time, we can find better readers among adolescents with ID (who can read faster, make fewer mistakes) who, despite having a good reading technique still do not reach the expected level of reading comprehension - their reading problems cannot therefore be fully explained by the reading technique. These research findings show that additional attention needs to be paid to identifying important factors affecting the reading of more successful readers with ID, as their difficulties require a different instructional response.

The second viewpoint of explaining reading characteristics of students with ID is provided by research on the structural differences in reading literacy among students with ID and students of TD (e.g. Channell et al., 2012), which explain the differences between the groups even in the case of older students. The starting point of these types of research is often a comparison of reading literacy (as well as its individual components) of students with ID and younger students of TD (e.g. Channell et al., 2012; Van Tilborg et al., 2014). A similar approach was used in our study, whereby we used the functional aspect of reading literacy as a supplementary criterion (expected reading achievements, in accordance with the standards from the curriculum for AP LES and the curriculum standards for the educational program with equivalent educational standards). Results of prior research show that in addition to slower development, reading difficulties of students with ID can be explained through certain cognitive factors relevant to reading. Among them, phonological processes (e.g. Channell et al., 2012) and working memory (e.g. Henry \& Winifield, 2010; Rosenquist et al., 2003) are highlighted most often. Even though students with ID make progress in reading later in their schooling as well (Jenkinson, 1989), their progress is slower and less prominent compared to students of TD. In the context of reading, students with ID are increasingly lagging behind expectations relative to their cognitive abilities, as their potential to comprehend the text (measured through listening) 
is much higher than what their reading achievements suggest (Isikdogan \& Kargin, 2010). The latter contributes to an increasing gap between the group of students with ID and students of TD. The problems and differences become even more apparent in higher grades, especially after the age of 11 (Cawley, 1964; Conners, 2003), when their peers of typical development already enter the stage of reading for learning (Lipec Stopar, 2005).

Conners (2003) associates the growing gap in reading literacy between students with mild ID (IQ 50-70) and students of TD with the difficulties the former group has with transferring and using their knowledge in reading tasks. Despite knowing the connections between letters and sounds, the students have difficulty in connecting phonemes in written words, which slows down the process of automatization and makes it difficult for them to focus on understanding the content. Some authors (Cawley, 1964; Jenkinson, 1989; Pečjak, 2010) have also pointed out prominent issues that students with ID have with the automatization of the reading technique. Authors often attribute the reason for the students' unsuccessful reading to their problems in phonological awareness and decoding (e.g. Barker, 2010; Conners, 2003; Sermier Dessemontet \& de Chambrier, 2015). A good reading technique is a prerequisite for progressing towards higher levels of reading development. The problems of students with ID indicate that this group of students stays on the alphabetic stage (Frith, 1985) or the full-alphabetic phase ${ }^{2}$ (Ehri, 2005) for a longer time and needs more time and support for moving on from the initial reading and decoding stage (Chall et al., 1990). On the other hand, Metsala (2011) attributes the root of the students' problems in phonological processing to their less developed vocabulary and its impact on the phonological sensitivity of the individual (less "pressure" on the mental lexicon is reflected in less well-designed ideas about the parts of words and differences between them). In explaining the growing differences in reading literacy between students with mild ID and students of TD, Merril et al. (2003) also note the lesser efficiency in processing the semantic and syntactic levels of language in children with ID. Difficulties with reading comprehension are the result of problems with the use of context, connecting the text content with previous knowledge, and the students' lack of control over their own reading comprehension (Merril et al., 2003). Due to the increasing complexity of texts and the changing role of reading (reading for learning) in later years of schooling, these abilities become more and more important (Conners, 2003).

Many studies on factors influencing reading comprehension in children with ID draw attention to the importance of some prerequisites for reading skills (e.g. memory, attention, perception) that, according to Levorato et al. (2009),

2 Alphabetic stage (Frith, 1985) and full-alphabetic phase (Ehri, 2005) are well-known terms in reading theory. They refer to a certain stage (or phase) of reading development. In the alphabetic stage reading involves student's establishing a strong letter-sound correspondence and using the alphabetical principle in reading of known and unknown words (even nonwords). 
carry a different weight than they do in children of TD. Conners (2003) states that phonological memory is among the most important predictors of reading achievements of students with mild ID. Soltani and Roslan (2013) have also confirmed that the contribution of phonological awareness, verbal short-term memory and rapid naming is important to the ability to decode text in a survey consisting of 60 adult readers with ID (aged 15-23, average IQ $=68$ ).

An overview of these characteristics and problems indicates that mastering reading presents a particularly demanding challenge for students with ID. Loveall and Conners (2013) even place reading lessons among one of the most demanding school activities for this group of students. The starting point for planning reading lessons in Slovenian primary schools that implement AP LES is the curriculum for the aforementioned program (Curriculum: adapted educational program with a lower educational standard: Slovene, proposal, 2003). The basics of reading lessons for students with ID in our country are similar to the basics of some foreign reading programs (e.g. Cunningham, 1999 as cite in Joseph \& McCachran, 2003) and derive from the guidelines for reading lessons for students of TD. The methods of literacy development and reading lessons that are considered effective for teaching students of TD can also be effectively used for students with ID (Allor et al., 2010; Barker, 2010), but at the same time we must take into consideration different abilities and other characteristics of this population (e.g. Saunders, 2007). The curriculum for AP LES fulfils this through the implementation of various adjustments and changes to the initial curriculum for nine-year elementary school, based on findings acquired through research and practical work in the field of teaching students with ID (Curriculum: adapted educational program with a lower educational standard: Slovene, proposal, 2003). Evaluating the literacy level achieved by the students in the programme and implementing the applied approaches requires careful monitoring of the students' achievements. The transition from early to late elementary school represents one of the key breakpoints for students, which in AP LES also coincides with the end of the systematic literacy development period.

\section{Research problem}

The basis of planning reading lessons in Slovenian elementary schools for students with mild ID is represented by the curriculum of AP LES (Curriculum: adapted educational program with a lower educational standard: Slovene, proposal, 2003). It predicts, similarly to educational programs providing equal educational standards, that by the end of the literacy development period, the students will have mastered reading techniques to the point of being able to focus their attention primarily on developing reading comprehension. Considering the numerous problems students with ID have in mastering reading, we want to find out the extent to which they are able to achieve this goal by the end of 
the systematic literacy development period in AP LES (fifth grade). In order to understand the characteristics of how students with ID read, an insight into the background of reading performance of this group of students is required. Studies that provide an insight into the reading literacy model of students with ID have not been previously executed in Slovenia; due to the different nature of the language and differences in educational systems, the findings of foreign research cannot be directly transposed to the population of students with ID in our country. When analysing reading difficulties of students with ID, many foreign studies derive from a comparison of reading literacy (or its individual components) of students of TD and students with ID (e.g. Channell et al., 2012; Van Tilborg et al., 2014). A similar starting point was also used in this study. We compared our findings on reading achievements of students with ID with the standardized norms, previously developed for Slovenian students of typical development at the end of their systematic literacy development period $\left(3^{\text {rd }}\right.$ grade) (Pečjak et al., 2012a, 2012b). By analysing the latent structure of reading literacy in fifth grade students in AP LES and comparing their achievements with the norms set for students of TD, we will gain a comprehensive and indepth insight into reading achievements of students with ID during the period that predicts the transition of students to the independent reading level. This kind of knowledge is a fundamental starting point for planning support for students with ID, oriented towards the optimal development of their reading potential.

\section{Objectives}

In this study we explain the latent structure of reading in a group of fifth grade students with ID, enrolled in AP LES. By forming a model of their reading literacy, we can gain a better insight into reading literacy factors of students with ID, which (in addition to their lower cognitive potential) contribute to deviations from typical reading development. Furthermore, we will show the comparison between the results of fifth grade students in AP LES in terms of individual reading factors (reading comprehension, reading technique, phonological awareness, reading interest) and the norms previously developed for Slovenian students with TD at the end of their systematic literacy development period (third grade) (Pečjak et al., 2012a, 2012b). Based on the results obtained we will design the recommendations for planning reading lessons in AP LES, which represent the applicative goal of our research work. 


\section{Method}

\section{Participants}

This study represents the first part of a wider research on the characteristics of reading of Slovenian elementary school students with mild ID (Jenko, 2016; Jenko \& Lipec Stopar, 2017, 2019). In this paper, we present the results obtained with a group of younger students in AP LES. Our sample consisted of 61 fifth grade students (average age of 11 years and 11 months; minimum 10 years and 5 months, maximum 13 years and 8 months), enrolled in AP LES, which represents $34 \%$ of fifth grade students in the aforementioned programme in the school year 2013/2014. The frequency of girls $\left(n_{1}=\right.$ $\left.27 ; P_{1}=44 \%\right)$ is lower than the frequency of boys $\left(n_{2}=34 ; P_{2}=56 \%\right)$, which is in line with the girl to boy ratio in the whole population of fifth grade students in AP LES. In order to ensure the homogeneity of the sample, we formed several guidelines that were considered when selecting students for the sample. These guidelines refer to the appropriate definition of a student with special needs (student with mild ID according to the Criteria for defining the type and level of disabilities, obstacles and disorders of children with special needs, 2015) $)^{3}$, orientation to the appropriate education program $(\mathrm{AP} \text { LES })^{4}$, the requirement for the students to take part in the literacy development process in Slovenian language and the exclusion of some students with multiple disabilities in case their problems had a significant impact on the performance and the results of the tests (additional moderate or severe motor impairment, hearing and / or visual impairment). In addition, we used non-verbal intelligence as a control variable to ensure the homogeneity of the sample (we excluded some students who scored significantly lower on the Raven's non-verbal intelligence test).

\section{Data collection and procedure}

Several tests were included in this survey. We observed how students function in various areas that are important for effective reading (visual and auditory processing, memory, rapid naming, sequencing and coding, linguistic ability, reading technique, reading comprehension, prior knowledge of texts. In Table 1, the observed variables are arranged according to individual fields of the structure of reading literacy with the tests we used to measure them. For each of the variables, we listed the name, value, time limit (if applicable), and other adjustments made when performing the tests.

To ensure a correct understanding of the instructions, the tests were carried out individually. We conducted five sessions with all students, each session lasting a maximum of 45 minutes. The psychological tests were conducted by school psychologists. We have already checked the metric characteristics of the tests used as part of the wider research (Jenko, 2016).

3 In accordance with Slovenian legal sources that regulate the education of children with special needs (Regulations for the organisation and work of the Commissions, 2013).

4 In accordance with the organization of the school system in Slovenia and the relevant national legal sources (Placement of Children with Special Needs Act, 2011). 
The acquired data was processed with descriptive and multivariate statistics. Using exploratory factor analysis, we analysed the characteristics of this group's reading literacy. In addition to our findings, we also considered the results of students with ID in comparison to the norms created for students of typical development at the end of the literacy development period ( $3^{\text {rd }}$ grade).

The differences in the readers' achievements (arithmetic mean) in individual tests (Test SL40) were analysed using a $t$-test.

\section{Table 1}

Variables, tests and adjustments of the tests used

\begin{tabular}{|c|c|c|}
\hline Variable & Test used (time limit) & Value and adjustments \\
\hline Nonverbal intelligence & $\begin{array}{l}\text { Raven's standard progressive matrices } \\
\text { (Raven et al. 1999) (unlimited time) }\end{array}$ & $\begin{array}{l}0-36 \\
\text { individual application }\end{array}$ \\
\hline $\begin{array}{l}\text { Processing visual infor } \\
\text { Visual discrimination, } \\
\text { synthesis }\end{array}$ & $\begin{array}{l}\text { mation } \\
\text { Test of developmental abilities - ACADIA } \\
\text { (Atkinson et al., } 1972 \text { as cited in Novosel, } \\
\text { 1989), subtest } 3 \text { (unlimited time) }\end{array}$ & $\begin{array}{l}0-20 \\
\text { instructions }\end{array}$ \\
\hline $\begin{array}{l}\text { Phonological processin } \\
\text { Phonological } \\
\text { awareness }\end{array}$ & $\begin{array}{l}\text { g } \\
\text { The reading abilities evaluation scheme } \\
\text { (OSBZ) } 2 \text { and } 3 \text { (Pečjak et al. as cited in } \\
\text { Pečjak et al., 2012c), } 7 \text { tasks (unlimited } \\
\text { time) }\end{array}$ & $\begin{array}{l}0-26 \\
\text { instructions, test design }\end{array}$ \\
\hline $\begin{array}{l}\text { Memory } \\
\text { Auditory memory }\end{array}$ & ACADIA, subtest 8 (unlimited time) & $\begin{array}{l}0-20 \\
\text { instructions, writing down } \\
\text { answers }\end{array}$ \\
\hline Visual memory & $\begin{array}{l}\text { Special Needs Assessment Profile - } \\
\text { SNAP (Weedon \& Reid, 2009), subtest } 9 \\
\text { (unlimited time) }\end{array}$ & $0-12$ \\
\hline $\begin{array}{l}\text { Rapid automatized nan } \\
\text { Rapid automatized } \\
\text { naming - time }\end{array}$ & $\begin{array}{l}\text { Rapid automatized naming test - RAN } \\
\text { (Denckla \& Rudel, } 1974 \text { as cited in Jelenc, } \\
\text { 1996) }\end{array}$ & time in seconds \\
\hline $\begin{array}{l}\text { Processing sequences } \\
\text { Sequence and coding }\end{array}$ & ACADIA, subtest 7 (unlimited time) & $\begin{array}{l}0-20 \\
\text { instructions }\end{array}$ \\
\hline \multicolumn{3}{|l|}{ Language ability } \\
\hline $\begin{array}{l}\text { Vocabulary } \\
\text { (and linguistic } \\
\text { reasoning) }\end{array}$ & $\begin{array}{l}\text { Test "Vocabulary" (Lipec Stopar, 2005) } \\
\text { (unlimited time) }\end{array}$ & $\begin{array}{l}0-40 \\
\text { instructions, test, execution, } \\
\text { writing down answers }\end{array}$ \\
\hline $\begin{array}{l}\text { Listening } \\
\text { comprehension of } \\
\text { sentences (SL40) }\end{array}$ & $\begin{array}{l}\text { Auditory and reading comprehension test } \\
\text { - SL40 (Nielsen et al., } 1986 \text { as cited in } \\
\text { Lipec Stopar, 2005) (unlimited time) }\end{array}$ & $\begin{array}{l}0-20 \\
\text { test format and design }\end{array}$ \\
\hline $\begin{array}{l}\text { Word recall, word fluer } \\
\text { Word fluency } \\
\text { (semantic fluency) }\end{array}$ & $\begin{array}{l}\text { cy (language expression) } \\
\text { SNAP, subtest } 7 \text { (limited time) }\end{array}$ & $\begin{array}{l}\text { number of properly listed } \\
\text { words } \\
\text { instructions }\end{array}$ \\
\hline
\end{tabular}




\begin{tabular}{|c|c|c|}
\hline Variable & Test used (time limit) & Value and adjustments \\
\hline $\begin{array}{l}\text { Decoding (reading technique) } \\
\text { Level of automaticity in silent } \\
\text { reading (rate) - silent reading } \\
\text { in one minute } \\
\text { (Quality of) oral reading - rate } \\
\text { (Quality of) oral reading } \\
\text { - Accuracy, Accuracy } \\
\text { (percentage), Errors (number), } \\
\text { Expressiveness, Rhythm }\end{array}$ & $\begin{array}{l}\text { The reading abilities evaluation } \\
\text { scheme (OSBZ-3/1 K), text A "Garden } \\
\text { on the Windowsill" ( } 1 \text { minute) } \\
\text { The reading abilities evaluation } \\
\text { scheme (OSBZ-3/2 K), text "Afternoon } \\
\text { with Dad" (max. } 7 \text { minutes) }\end{array}$ & $\begin{array}{l}\text { number of words per } \\
\text { minute } \\
\text { number of words read } \\
\text { per minute } \\
\text { percentage of correctly } \\
\text { read words } \\
\text { number of mistakes } \\
\text { score } 1-3 \\
1 \text { - uneven }\end{array}$ \\
\hline & & 2 - even \\
\hline $\begin{array}{l}\text { Reading comprehension } \\
\text { Reading comprehension of } \\
\text { long text }\end{array}$ & $\begin{array}{l}\text { The reading abilities evaluation } \\
\text { scheme- } 3 / 3 \mathrm{~K} \text {, text "Red Fox" long text } \\
\text { (unlimited time) }\end{array}$ & $\begin{array}{l}0-9 \\
\text { text format and design }\end{array}$ \\
\hline $\begin{array}{l}\text { Reading comprehension rate - } \\
\text { number of all tasks completed } \\
\text { Reading comprehension rate } \\
\text { - number of tasks executed } \\
\text { correctly }\end{array}$ & $\begin{array}{l}\text { Reading test - comprehension rate } \\
\text { subtest } \\
\text { (Pečjak \& Potočnik as cited in Pečjak } \\
\text { et al., } 2012 \text { b), short texts ( } 7 \text { minutes } \\
\text { and } 30 \text { seconds) }\end{array}$ & $\begin{array}{l}0-20 \\
\text { instructions, execution }\end{array}$ \\
\hline $\begin{array}{l}\text { Reading comprehension level - } \\
\text { number of all tasks completed } \\
\text { Reading comprehension level } \\
\text { - number of tasks executed } \\
\text { correctly }\end{array}$ & $\begin{array}{l}\text { Reading test - level of comprehension } \\
\text { subtest } \\
\text { longer texts ( } 10 \text { minutes) }\end{array}$ & \\
\hline $\begin{array}{l}\text { Reading comprehension of } \\
\text { sentences (SL40) - number of } \\
\text { all examples solved } \\
\text { Reading comprehension of } \\
\text { sentences (SL40) - number of } \\
\text { examples solved correctly }\end{array}$ & $\begin{array}{l}\text { Listening and reading comprehension } \\
\text { test - SL } 40 \\
\text { short texts ( } 5 \text { minutes) } \\
\text { Listening and reading comprehension } \\
\text { test - SL } 40 \\
\text { short texts ( } 5 \text { minutes) }\end{array}$ & $\begin{array}{l}0-20 \\
\text { test format and design }\end{array}$ \\
\hline
\end{tabular}

\section{Results and discussion}

Table 2 shows descriptive statistics for the variables included in factorisation. In analysing students' reading performance, we have also included some other variables, which will be presented later.

The heterogeneity of the population contributes to scattered results for most of the variables observed. It is most pronounced for those variables that measure the rate and accuracy of task completion (within a limited time frame) and for those tasks that do not have a fixed upper value for their results (number of reading errors, reading accuracy, reading rate). A lower dispersion of results around the mean value is observed for variables that relate to areas where students with ID face greater difficulties (e.g. auditory memory, word fluency, reading comprehension, reading rate, vocabulary). Tasks requiring 
fast and accurate reading, reading comprehension, memorization and quick retrieval of information were particularly demanding for most students with ID. Nevertheless, the sensitivity of these tests is still appropriate. The variables presented were prepared for further statistical analysis (normalisation and use of standard T-values).

\section{Table 2}

Descriptive statistics - fifth grade students in AP LES $(N=61)$

\begin{tabular}{lcccc}
\hline Variables & Min & Max & $M$ & $S D$ \\
\hline Nonverbal intelligence & 10 & 51 & 23.60 & 8.48 \\
Visual discrimination & 7 & 17 & 13.61 & 2.55 \\
Sequence and coding & 5 & 16 & 9.87 & 1.90 \\
Auditory memory & 1 & 9 & 4.80 & 2.50 \\
Visual memory & 0 & 10 & 5.97 & 2.25 \\
Word fluency & 1 & 15 & 7.13 & 2.91 \\
Rapid automatized naming - time & 126 & 337 & 191.88 & 46.66 \\
Phonological awareness & 3 & 25 & 15.34 & 4.70 \\
Listening comprehension - sentences & 7 & 20 & 16.18 & 2.90 \\
Reading comprehension - sentences & 2 & 17 & 8.42 & 3.18 \\
Oral reading - rate & 20 & 161 & 66.56 & 30.23 \\
Oral reading - errors & 4 & 94 & 29.46 & 16.82 \\
Oral reading - accuracy & 26 & 366 & 290.74 & 80.26 \\
Oral reading - accuracy (percentage) & 38 & 99 & 88.88 & 9.90 \\
Reading comprehension rate - all & 5 & 25 & 15.33 & 6.12 \\
Reading comprehension rate - correct & 1 & 24 & 9.46 & 5.39 \\
Reading comprehension level - all & 2 & 20 & 12.63 & 5.45 \\
Reading comprehension level - correct & 0 & 13 & 5.70 & 3.00 \\
Silent reading - rate (1 minute) & 12 & 198 & 74.49 & 41.73 \\
Reading comprehension - long text & 2 & 9 & 5.30 & 1.69 \\
Vocabulary & 10 & 37 & 20.21 & 6.00 \\
\hline
\end{tabular}

In order to gain a more detailed insight into the background of reading skills of fifth-graders in AP LES, we used factor analysis to determine the latent factors that explain a large portion of the variance of the system of observed variables, thus fulfilling the first goal of our research. A correlation matrix between manifest variables is attached in the appendix. Before factorization, we checked the conditions for the application of factor analysis. The Kaiser-MeyerOlkin test $(\mathrm{KMO}=.82)$ and the Bartlett test $\left(\chi^{2}(190)=713.13 ; p<.0001\right)$ show that the percentage of the total variance of the variable system (caused by latent factors) is large enough to allow factorization. The system of variables meets the conditions for the application of factor analysis. The factors were extracted following the Hotelling method of principal components. According to the Kaiser-Guttman criterion $(\lambda>1)$ we retained five factors that explain $70.5 \%$ of the total variance of manifest variables. These factors were orthogonally rotated by employing varimax rotation and structure matrix is presented in Table 3 . 
Table 3

Structure matrix after rotation (varimax) - fifth grade students in AP LES

\begin{tabular}{|c|c|c|c|c|c|}
\hline \multirow{2}{*}{ Manifest variables } & \multicolumn{5}{|c|}{ Factors } \\
\hline & 1 & 2 & 3 & 4 & 5 \\
\hline T_Silent reading - rate & .92 & & & & \\
\hline $\mathrm{T}$-Oral reading - rate & .90 & & & & \\
\hline T_Reading comprehension rate - all & .90 & & & & \\
\hline $\mathrm{T}_{-}$Reading comprehension rate - correct & .83 & & & & \\
\hline $\mathrm{T}_{-}^{-}$Reading comprehension level - all & .81 & & & & \\
\hline T_Oral reading - accuracy & .75 & & & & \\
\hline $\mathrm{T}_{-}$Reading comprehension level - correct & .74 & & & & \\
\hline T_Rapid naming & -.71 & & & -.39 & \\
\hline T_Reading comprehension - sentences & .69 & .48 & & & \\
\hline T_Visual memory & & .78 & & & \\
\hline T_Visual discrimination & & .73 & & & \\
\hline $\mathrm{T}_{-}^{-}$Listening comprehension - sentences & & .64 & & & \\
\hline T_Nonverbal intelligence & & .55 & .41 & & \\
\hline T_Reading comprehension - long text & & & .75 & & \\
\hline T_Vocabulary & & & .71 & & \\
\hline $\mathrm{T}_{-}^{-}$Phonological awareness & & & .68 & & \\
\hline T_Oral reading - errors & & & -.60 & & .41 \\
\hline $\mathrm{T}_{-}$Sequence and coding & & & & .86 & \\
\hline T_Auditory memory & & & & .33 & .32 \\
\hline T_Word fluency & & & & & .82 \\
\hline
\end{tabular}

Note. Only saturations above .40 are presented.

As previously described, we identified five factors that explain reading literacy of this group of students.

Factor 1, known as "reading efficiency", explains most of the variance of the variable system (36.8\%) and is saturated with nine variables that relate to the rate and level of reading comprehension within a limited time frame. In younger students, success in solving these tasks is related to the ratio of correctly read words to all words read in the text (oral reading accuracy). Reading efficiency of fifth-graders is particularly related to the automatization of the processes necessary for reading. Poor reading technique is reflected in numerous reading errors, which makes reading comprehension even more difficult.

Factor 2, named "processing of visual information and listening comprehension", explains $15.4 \%$ of the variance of the variable system. The factor combines four variables and indicates the important role of visual information processing in the latent reading structure of fifth-graders. All items are somehow related to the processing of different visual information (words or images). The tests we used to measure these variables require the ability to store and process non-verbal visual information, to distinguish visually similar sets of letters (non-words), and also listening (language) comprehension. 
Students must be familiar with letters, be able to distinguish between them and remember their shapes. Without all this, decoding is impossible (Hoover \& Gough, 1990 as cited in Wren, 2001). Due to their lower intellectual potential, students with ID require more time to automatize individual components of the reading process, which justifies the need for a prolonged process of systematic literacy development. The high saturation of the factor with variables related to listening and reading comprehension (Listening/Reading comprehension sentences) can be attributed to the nature of one of the tests used, which requires students to link a short text (which they must either listen to or read themselves) with the corresponding illustration, distinguishing between similar images. The ability to link auditory information to its visual representation is also important in making connections between sounds and letters. Because of the lower intellectual potential, the formation of associative connections between letters and sounds requires more practice. This factor leads to the need for adaptations in the design of the text for younger learners.

Factor 3, called "phonological awareness and vocabulary", explains $7.2 \%$ of the variance of the variable system. The factor combines four variables related to vocabulary, reading comprehension, phonological awareness and oral reading errors. Students with better phonological awareness made fewer mistakes. Phonological awareness is also related to vocabulary, which has been confirmed by other authors (e.g. Metsala, 2011). Due to students with ID having a less extensive vocabulary compared to children of $\mathrm{TD}$, there is less pressure on the mental lexicon, which also influences the development of phonological sensitivity to similar sounding words. In younger students with ID, the ability of phonological awareness and building a vocabulary are, similarly to learning, discriminating and memorising letters, related to the intellectual potential of the individual. At the same time, their reduced intellectual potential makes it difficult for students to recognise relationships between words. Nevertheless, the perception and processing of visual information (factor 2) play a more important role in the latent reading structure of students with ID.

Factor 4, called "processing sequences", explains $6 \%$ of the variance of the variable system. This factor combines two variables which both require direct auditory memory and sequence processing. Processing symbol sequences and maintaining the perception of these sequences are critical to the effective decoding of words. Preserving information in memory is also imperative for manipulating with words and information from the text (Gathercole \& Baddeley, 1993 as cited in Rathvon, 2004). The nature of the tests used also contributes to the fact that memorization and recognition of sequences plays a lesser role in the latent reading structure of fifth-graders, as they usually require deductions. The student must first recognise the relationship between the symbols shown (a certain rule) and then continue the sequence, a skill that is not yet so strongly developed by fifth graders with ID (more attention is paid to reading technique 
than comprehension). Younger students are also exposed to shorter texts, which puts less strain on memory. The ability to memorise information therefore plays a lesser role in explaining their latent reading structure.

Factor 5, called "word recall rate", explains 5.1\% of the variance of the variable system. This factor is most heavily saturated with the variable that requires students to have a fast word recall on a particular topic (word fluency). The variable is strongly related to vocabulary, auditory memory, phonological awareness and listening comprehension (see Correlation Matrix in Appendix). Errors in oral reading refer to success in retrieving words from long-term memory. When reading, the student needs to quickly recall the names of letters, make connections between words and their meanings, etc. The latter is a reflection of several factors. Among the more important ones are the student's comprehension potential or the quality and extent of his or her knowledge base (e.g. range of vocabulary, ability to understand by listening), the ability to detect minuscule differences between audible information (e.g. distinguishing between similar sounding sounds or words) and the ability to retain and process audible information in memory (auditory short-term memory and working memory).

The main factor of reading ability in fifth grade students is their (lack of) automaticity of reading processes (factor 1). Reading success in the fifth grade is still linked to the perceived maturity of the individual and his/her abilities of visual discrimination (factor 2), which are particularly important in learning letters, differences between them, etc. Their unintegrated reading technique is also reflected in the amount and type of reading errors. Our observations (Jenko, 2016) show that some of the most common mistakes include adding and omitting letters or sounds, substituting letters for visually similar ones or letters with a similar sound, guessing and deforming words. Students still use lower-level strategies in word recognition (e.g. regression as repeated reading of the same line of the text) and slowly spell out words or read them by syllables.

An important role in explaining reading difficulties of fifth grade students in AP LES is played by phonological processes, especially phonological awareness. It has an important (negative) correlation with reading accuracy (the correlation between phonological awareness and the number of errors in oral reading is $(r=-.41, p<.01)$, with which students with ID struggle significantly. Students who were better at solving tasks related to phonological awareness made fewer errors and vice versa.

Table 4 shows the correlations between certain variables. The results confirm the findings of foreign authors (Wolf \& Goodglass, 1986 as cited in Jelenc, 1996) on the correlation between reading ability and rapid naming in students of TD. Naming rates are associated with word decoding (a high and significant correlation with the rate of oral reading). Rapid naming also plays an important role in reading comprehension of short texts and auditory memory. For students with ID, rapid naming remains significantly linked to reading 
success even up to the fifth grade. Similar results were obtained by Saunders and De Fulio (2007 as cited in Soltani \& Roslan, 2013) in their analysis of the correlations among adult readers with ID. Compared to students of TD, reading ability of students with ID, is based on lower level processes (decoding, word recognition) for a longer time. Due to their less developed phonological processes, students with ID require more time to learn decoding (Sermier Dessmontet \& de Chambrier, 2015).

\section{Table 4}

Correlations between variables and statistical significance

\begin{tabular}{lcccccccc}
\hline Variables & 1 & 2 & 3 & 4 & 5 & 6 & 7 & 8 \\
\hline 2 & $-.31^{*}$ & & & & & & & \\
3 & -.24 & $.35^{* *}$ & & & & & & \\
4 & -.17 & $.33^{* *}$ & .23 & & & & & \\
5 & $-.43^{* *}$ & $.33^{*}$ & $.32^{*}$ & $.30^{*}$ & & & & \\
6 & $-.60^{* *}$ & .22 & .24 & -.02 & $.63^{* *}$ & & & \\
7 & -.08 & .21 & $.44^{* *}$ & .18 & $.29^{*}$ & .12 & & \\
8 & -.03 & $.34^{* *}$ & $.45^{* *}$ & $.40^{* *}$ & .20 & .02 & $.44^{* *}$ & \\
\hline
\end{tabular}

Note. 1 - Rapid naming; 2 - Auditory memory; 3 - Phonological awareness; 4 - Listening comp. of sentences; 5 - Reading comp. of sentences; 6 - Oral reading - rate; 7 - Reading comp. of long text; 8 - Vocabulary

${ }^{*} p \leq .05 ;{ }^{* *} p \leq .01$

Table 4 shows some variables that are relevant for explaining the relationship between phonological awareness, language and other reading variables. The relationship between phonological awareness and language in students with ID (Table 4) is similar to that in students of TD, reported by other researchers (e.g. Metsala \& Walley, 1998 as cited in Goswami, 2001; Metsala, 2011). Students with better vocabulary are more successful in tasks involving phonological awareness, which confirms the findings of other authors (e.g. Metsala \& Walley, 1998 as cited in Goswami, 2001; Metsala, 2011) on correlations between the acquisition of vocabulary and the development of phonological awareness among students with ID as well. Both are importantly related to the intellectual potential of an individual. Similarly, Pogačnik (1995) stresses the important role of intellectual potential in language acquisition (vocabulary, relationships between words). Vocabulary is one of the basic components of language comprehension (Hoover \& Gough, 1990 as cited in Wren, 2001) and is important for determining the level of reading comprehension (Davis, 1968 in Pečjak \& Gradišar, 2002). In addition to the scope of the reader's vocabulary, the structure of reading vocabulary is also important (Pečjak, 1999), i.e. the way terms are connected and organized. For students with ID, all these are 
expressed mainly in situations where they can demonstrate their comprehension skills in unlimited time (see item Reading comprehension of long text - test with unlimited time in Table 1; Jenko, 2016).

The results of fifth grade students with ID and their comparison with the results of other authors on adolescent and adult readers with ID (Soltani \& Roslan, 2013) complement the explanation of their slower reading development by explaining the reasons for the persistence of reading difficulties in students with ID even at the end of an intensive systematic literacy development period. The results show that phonological processes are the reasons for the qualitative deviations from typical reading development in students with ID. In the field of phonological processes, people with ID make the least (or slowest) amount of progress. Soltani and Roslan (2013) find that phonological processes have a significant impact on the ability to decode even later, in adolescents and adult readers with ID $(15-23$ years old, mean IQ $=68)$. Due to poor reading technique, the role of comprehension potentials is less important in fifth grade students with ID (compared with the variables relevant to mastering reading technique). This is also confirmed by the degrees of correlation and their statistical significance between the variables indicating automatization of reading technique (oral reading rate, accuracy) and language comprehension (vocabulary, listening comprehension) with reading comprehension (short and long texts) among students in AP LES (Table 5). Language (listening) comprehension and decoding rate are significantly related to reading comprehension of fifth grade students with ID. The high (positive) correlation between the rate and accuracy of reading (reading technique) and reading comprehension is particularly striking.

\section{Table 5}

Correlations between language comprehension, decoding and reading comprehension - fifth grade students in AP LES

\begin{tabular}{lcc}
\hline Variables & $\begin{array}{c}\text { Short text } \\
\text { Reading comp. of sentences / } \\
\text { Reading comp. rate - correct }\end{array}$ & $\begin{array}{c}\text { Long text } \\
\text { Reading comp. level - correct }\end{array}$ \\
\hline Language comprehension & $.19 / .20$ & .13 \\
Vocabulary & $.31^{*} / .12$ & .19 \\
Listening comprehension & & $.57^{* * *}$ \\
Decoding (reading technique) & $.66^{* * *} / .76^{* * *}$ & $.48^{* * *}$ \\
Oral reading - rate & $.64^{* * *} / .70^{* * *}$ & \\
Oral reading - accuracy & &
\end{tabular}

Fifth-grade students with ID are able to understand more than they can read, as evidenced by statistically significant differences in listening and reading comprehension tests (Table 6). 


\section{Table 6}

Comparison between listening and reading comprehension - fifth grade students in AP LES

\begin{tabular}{lcccccc}
\hline & $M$ & $N$ & $S D$ & $t$ & $d f$ & $p$ \\
\cline { 1 - 4 } Listening comprehension of sentences & 16.18 & 61 & 2.90 & \multirow{2}{*}{16.71} & \multirow{2}{*}{60} & $<.001$ \\
\hline Reading comprehension of sentences & 8.42 & 61 & 3.18 & & & \\
\hline
\end{tabular}

Among fifth grade students in AP LES, a balance of language (listening) and reading comprehension, which is assumed by the initial reading model by Gough and Tunmer (1985 in Wren, 2001; Hoover \& Gough, 1990), does not occur. The main reason for that is poor reading technique, linked with inadequate visual and phonological processes, which are important for reading.

An additional insight into the reading literacy of fifth grade students in AP LES was obtained by analysing the individual factors of reading comprehension of students in AP LES (reading rate and accuracy, the rate and level of reading comprehension, phonological awareness, etc.) and their comparison with the norms applicable to students of TD at the end of the literacy development period (at the end of the third grade) (Pečjak et al., 2012a, 2012b), thus completing the second goal of our research. Our findings are presented in the tables below (Tables 7 and 8).

\section{Table 7}

Minimum, maximum, average percentiles achieved and standard deviation (SD) for each observed variable - fifth grade students in AP LES $(\mathrm{N}=61)$

\begin{tabular}{lcccc}
\hline Variable & Min & Max & $M$ & SD \\
\hline Reading comprehension rate - all & 1 & 99 & 51.25 & 33.59 \\
Reading comprehension level - all & 0 & 98 & 42.83 & 38.85 \\
Reading comprehension rate - correct & 5 & 100 & 41.22 & 26.02 \\
(Quality of) oral reading - rate & 0 & 95 & 34.66 & 30.61 \\
(Quality of) oral reading - accuracy & 0 & 90 & 30.42 & 18.73 \\
Reading comprehension level - correct & 0 & 82 & 27.53 & 21.48 \\
Level of automaticity in silent reading & 0 & 90 & 26.71 & 25.98 \\
Reading comprehension & 0 & 80 & 22.75 & 19.95 \\
Phonological Awareness - sound segmentation & 0 & 60 & 20.67 & 24.17 \\
Phonological Awareness - deleting sounds & 0 & 70 & 17.08 & 19.25 \\
Phonological Awareness - blending sounds & 0 & 60 & 15.33 & 18.36 \\
Phonological Awareness - deleting syllables & 0 & 70 & 14.33 & 21.68 \\
Oral Reading - rhythm & 0 & 20 & 8.47 & 9.97 \\
Oral Reading - expressiveness & 0 & 30 & 8.33 & 10.28 \\
Oral Reading - errors & 0 & 60 & 6.79 & 14.93 \\
\hline
\end{tabular}




\section{Table 8}

A comparison of the achievements of fifth grade students in AP LES with the norms for students of typical development at the end of the third grade

\begin{tabular}{|c|c|c|c|c|c|c|}
\hline \multirow{2}{*}{ Variable } & \multicolumn{6}{|c|}{$\begin{array}{l}\% \text { of students achieving an individual } \\
\text { percentile value }\end{array}$} \\
\hline & up to 10 & $11-20$ & $21-40$ & $41-60$ & $61-80$ & above 80 \\
\hline Reading comprehension rate - all & 15.0 & 6.7 & 16.7 & 23.3 & $8.3^{*}$ & $30.0^{*}$ \\
\hline Reading comprehension level - all & 36.7 & 3.3 & $21.7^{*}$ & 3.3 & $6.7 *$ & 25.0 \\
\hline $\begin{array}{l}\text { Reading comprehension rate - } \\
\text { correct }\end{array}$ & 3.3 & 21.7 & $36.7^{*}$ & $13.3^{*}$ & $15.0^{*}$ & $10.0^{*}$ \\
\hline (Quality of) oral reading - rate & 28.3 & 16.7 & 13.3 & 13.3 & 21.7 & 6.7 \\
\hline (Quality of) oral reading - accuracy & 3.3 & 15.0 & 65.0 & $10.0^{*}$ & $1.7^{*}$ & $5.0^{*}$ \\
\hline $\begin{array}{l}\text { Reading comprehension level - } \\
\text { correct }\end{array}$ & 26.7 & 21.7 & $23.3^{*}$ & $11.7^{*}$ & 11.7 & $1.7^{*}$ \\
\hline $\begin{array}{l}\text { Level of automaticity in silent } \\
\text { reading }\end{array}$ & 36.7 & 13.3 & 23.3 & $11.7^{*}$ & $11.7^{*}$ & 3.3 \\
\hline Reading comprehension - long text & 33.3 & 18.3 & $41.7^{*}$ & 0.0 & $6.7^{*}$ & \\
\hline $\begin{array}{l}\text { Phonological awareness - sound } \\
\text { segmentation }\end{array}$ & 73.3 & & $26.7^{*}$ & & & \\
\hline $\begin{array}{l}\text { Phonological awareness - deleting } \\
\text { sounds }\end{array}$ & 55.0 & 25.0 & $13.3^{*}$ & 0.0 & $6.7^{*}$ & \\
\hline $\begin{array}{l}\text { Phonological awareness - blending } \\
\text { sounds }\end{array}$ & 53.3 & & 5.0 & $11.7^{*}$ & & \\
\hline $\begin{array}{l}\text { Phonological awareness - deleting } \\
\text { syllables }\end{array}$ & 70.0 & $13.3^{*}$ & 6.7 & & $10.0^{*}$ & \\
\hline Oral Reading - rhythm & 56.7 & $41.7^{*}$ & & & & \\
\hline Oral Reading - expressiveness & 85. & & $15.0^{*}$ & & & \\
\hline Oral Reading - errors & 81.7 & $6.7 *$ & $6.7 *$ & $5.0^{*}$ & 0.0 & 0.0 \\
\hline
\end{tabular}

Note. * Predominantly students who are among good readers

The majority of students reach lower percentile values in the observed variables. For almost all variables, more than $40 \%$ of the fifth graders in the sample ranked up to the 40th percentile.

The largest proportion of students ranked up to the 10th percentile is found in variables that relate to phonological awareness and to the different criteria of fluent reading (accuracy, errors, expressiveness, rhythm) (Table 8). This means that a large proportion of students with ID has poorly developed phonological awareness skills and does not meet the minimum criterion for the mentioned variable. Their difficulties are even more pronounced in tasks requiring memorization and manipulation of letter sounds or syllables (especially the synthesis of multiple sounds into a longer word, removing sounds and syllables). These are tasks that put additional strain on auditory memory and cause significant problems for students with ID (Conners, 2003). 
Approximately $80 \%$ of students in the sample are in the 10th percentile with their number of reading errors (and therefore belong to the $10 \%$ of students who make the most errors in reading).

A comparison of the mean percentile values in the subtests measuring the reading rate, reading comprehension rate and reading comprehension level (Reading test by Pečjak \& Potočnik, Table 8), shows, that fifth grade students with ID on average achieve higher percentile values for variables related to the amount of tasks solved in an individual test (Reading comprehension rate all and Reading comprehension level - all) and lower in variables regarding the amount of correct answers in the same subtests (Reading comprehension rate - correct, Reading comprehension level - correct). This means that while students are able to read quickly (despite it still being average or below average according to the norms), they face more problems in understanding the read content. The gap between reading rate and the ability to understand content increases along with the length and complexity of the texts.

An even clearer image of the needs of students in AP LES can be formed through a comparison of the characteristics of the students' oral reading with the reading levels described in literature (Johnson et al., as cited in Pečjak, 2010). Based on the percentage of accurately read words in oral reading by the students in the sample, we found that:

- in 3.3\% of students, reading accuracy is $65 \%$ or less

- in $15 \%$ of students, reading accuracy is between $66 \%$ and $84 \%$

- in $45 \%$ of students, reading accuracy is between $85 \%$ and $92 \%$

- in $18.5 \%$ of students, reading accuracy is between $93 \%$ and $96 \%$

- in $13.3 \%$ of students, reading accuracy is between $97 \%$ and $98 \%$

- in $8.3 \%$ of students, reading accuracy is above $98 \%$.

Taking reading accuracy of fifth grade students in AP LES into account (Quality of oral reading - accuracy), we can conclude that for more than half of the sample, the so-called "frustration reading level" is typical, approximately $30 \%$ can be placed in instructional reading level, and barely over $8 \%$ of the students reach the independent reading level.

\section{Conclusion}

A parallel can be drawn between the performance of fifth graders in AP LES and that of less successful students of TD. Exceptions can be found in some better readers in AP LES. We can conclude that the reading efficiency of

$5 \quad$ Literature describes frustration level of reading as reading accuracy below $90 \%$ (Johnson et al., 1990 as cited in Pečjak, 2010). We slightly adjusted the groups and percentages based on the distribution of students by percentile values. Only the criterion of accuracy in oral reading was considered, even though other criteria were also defined for classifying students to a certain reading level (silent reading, behaviour while reading). 
students with ID at the end of the literacy development period is still based on processes of a lower level (decoding). Reading problems of students with ID are complex in nature and relate to various factors of reading literacy.

In fifth grade students in AP LES, fast and accurate word recognition is hindered by their poor visual discrimination and phonological processes, especially phonological awareness and phonological memory. With regard to the tasks related to phonological awareness, those requiring memorization and manipulation with letter sounds are particularly difficult for them. When reading orally, they still make several mistakes and often rely on guessing. For this reason, fifth grade students in AP LES are unable to use their full comprehension potential when reading. The discrepancy between linguistic (listening) and reading comprehension among students in AP LES is largely due to reading technique. Nevertheless, in explaining the reasons for the deviation from typical reading development, we cannot overlook the problems students have in understanding and following the content of the text. From the gap between the number of reading tasks completed and the number of correctly solved reading tasks, we can conclude that, as students age, reading factors related to the second component of the initial reading model (language comprehension) (Hoover \& Gough, 1990) are among the reasons for poor reading performance that will become increasingly prominent.

The students' reading performance shows the complexity of the correct planning of reading lessons in AP LES and the support given to these students. Teachers need to adapt their work to the needs of the students, regardless of the assumptions of the curriculum, which predicts, both in programs with lower educational standards (Curriculum: adapted educational program with a lower educational standard: Slovene, proposal, 2003) and those with equal educational standards (Poznanovič Jezeršek et al., 2013), that by the end of the literacy development period, the students will have adopted reading technique to the extent that their attention can be focused primarily on the development of reading comprehension. According to the results of our research, we cannot achieve this in full at the end of the literacy development period in AP LES. For more than half of fifth grade students in our sample, the frustration reading level is typical. According to our study and findings of other authors (e.g. Conners, 2003; Channell et al., 2012), reading difficulties of students with ID are definitely caused by several reasons, ranging from the characteristics of the students themselves and teaching approaches to other broader factors (characteristics of the home environment, conditions at school, how (un)suitable the educational requirements are for the characteristics and needs of the student, etc.).

Based on our results and prior findings of other studies (e.g. Allor etal., 2010; Conners, 2003; Channell et al., 2012) we can give different recommendations for planning reading lessons in AP LES. Special characteristics of reading lessons for students with ID can be defined from three aspects (Jenko, 2016). 
General methodological features of instruction for students with ID refer to more intensive, systematic, structured and explicit teaching. Reading difficulties of students with ID require an intensive, systematic and clearly structured work from the teacher, which includes effective methods of holistic literacy as well as explicit teaching of skills with which the students have the greatest difficulties. Teachers need to think carefully about how the knowledge acquired in class can be transferred in advance to new contexts and situations, and they need to be able to provide longer and more systematic guidance in the acquisition of skills (modelling, demonstration of processes) and in continuous monitoring of progress. The intensity of teaching reading should occasionally be increased by additional work and activities outside the classroom. As students have considerable difficulties with reading comprehension, it is necessary to carefully determine, in the planning phase of lessons, which tasks they can carry out independently. The above-mentioned special teaching requirements go beyond pure reading lessons and can also be applied to other subject areas that students with ID deal with.

Among the specific methodological guidelines for teaching (related to reading lessons) for students with ID, we must emphasize the need to practice reading techniques in higher grades. However, when practicing fast and accurate reading, in addition to appropriate amount of exercise, the rate must also be emphasized. Creating conditions that accelerate reading speed (and by gradually increasing the required speed) is important to ensure the effectiveness of reading training (automaticity). In the initial stages of reading lessons, particular attention should be paid to the development of phonological awareness, which, in addition to intensive training, requires certain adaptations (concretization of sounds with symbols, use of visual illustrations to identify the position of a sound in a word, use of images and writing in word segmentation exercises, etc.). In addition to improving the students' reading technique through exercises, teachers need to guide students before, during and after reading with different approaches to understanding and constructing ideas about the text. In this context, we need to stress the importance of expanding vocabulary by giving explanations for more complex, unfamiliar words in the text and teaching the use of contextual and other strategies for understanding new words, combined with explicit teaching of vocabulary in other learning situations. At the same time, in order to achieve optimal reading comprehension of students with ID, it is important for teachers to read aloud various texts in class and actively discuss the content of the text. Students with ID have difficulties in memorizing texts while listening, which can be facilitated by reading the text repeatedly, taking turns reading, using visual illustrations for different tasks, etc.

Teachers must also take the characteristics of students with ID into account by adapting the content of the lesson (content specificities). This includes selecting appropriate texts, strategies for developing and maintaining reading 
interest, creating a reading need in everyday life and planning precise decoding lessons. Learning goals must also be defined in a meaningful way, both in terms of the characteristics of the text (content, difficulty) and in terms of students' abilities. Due to the heterogeneity of the population, teachers teaching in AP LES have to take great care to recognize and take into account the diverse needs of their students. According to the data from our research and the requirements of the curriculum, they have to adapt not only the working methods but also the requirements of teaching.

\section{References}

Allor, J. H., Champlin, T. M., Gifford, D. B., \& Mathes, P. G. (2010). Methods for increasing the intensity of reading instruction for students with intellectual disabilities. Education and Training in Autism and Developmental Disabilities, 45(4), 500-511.

Barker, R. M. (2010). Modelling phonological processing for children with mild intellectual disabilities: The relationship between underlying phonological abilities and associated language variables [doctoral dissertations, Georgia State University]. ScholarWorks @ Georgia State University. https://scholarworks.gsu.edu/psych_diss/77/

Cawley, J. F. (1964). Identifying reading problems of the underachieving mentally retarded child. The High School Journal, 48(3), 166-172.

Chall, J. S., Jacobs, V. A., \& Baldwin, L. E. (1990). The reading crisis: Why poor children fall behind. Harvard University Press.

Channell, M. M., Loveall, S. J., \& Conners, F. A. (2012). Strengths and weaknesses in reading skills of youth with intellectual disabilities. Research in Developmental Disabilities, 34(2), 776-787. https://doi.org/10.1016/j.ridd.2012.10.010

Conners, F. A. (2003). Reading skills and cognitive abilities of individuals with mental retardation. International Review of Research in Mental Retardation, 27(1), 191-229.

Conners, F. A., Carr, M. D., \& Willis, S. (1998). Is the phonological loop responsible for intelligence-related differences in forward digit span? American Journal on Mental Retardation, 103(1), 1-11. https://doi.org/10.1352/0895-8017(1998)103<0001:ITPL $\mathrm{RF}>2.0 . \mathrm{CO} ; 2$

Ehri, L. C. (2005). Learning to read words: Theory, findings, and issues. Scientific Studies of Reading, 9(2), 167-188. https://doi.org/10.1207/s1532799xssr0902_4

Frith, U. (1985). Beneath the surface of developmental dyslexia. In K. Patterson, J. Marshall, \& M. Coltheart (Eds.), Surface dyslexia: Neuropsychological and cognitive studies of phonological reading (pp. 301-330). Erlbaum.

Goswami, U. (2001). Early phonological development and the acquisition of literacy. In S. B. Neuman \& D. K. Dickinson (Eds.), Handbook of early literacy research (pp. 111-125). Guilford Press.

Harris, T. L., \& Hodges, R. E. (1995). The literacy dictionary: The vocabulary of reading and writing. International Reading Association.

Henry, L., \& Winfield, J. (2010). Working memory and educational achievement in children with intellectual disabilities. Journal of Intellectual Disability Research, 54(4), 354-365. https://doi.org/10.1111/j.1365-2788.2010.01264.x

Hoover, W. A., \& Gough, P. B. (1990). The simple view of reading. Reading and Writing, 2(2), 127-160. https://doi.org/10.1007/BF00401799 
Isikdogan, N., \& Kargin, T. (2010). Investigation of the effectiveness of the story-map method on reading comprehension skills among students with mental retardation. Educational Sciences: Theory and Practice, 10(3), 1509-1527.

Jelenc, D. (1996). Uporaba testa hitrega avtomatiziranega poimenovanja $\mathrm{v}$ procesu začetnega branja [Using the rapid automated naming test in the initial reading process]. Defektologica Slovenica, 4(1), 83-90.

Jenkinson, J. C. (1989). Word recognition and the nature of reading difficulty in children with an intellectual disability: A review. International Journal of Disability, Development and Education, 36(1), 39-56. https://doi.org/10.1080/0156655890360105

Jenko, N. (2016). Struktura in razvoj bralne pismenosti učencev v prilagojenem programu $z$ nižjim izobrazbenim standardom [The structure and development of reading literacy in the students attending the educational programme for children with mild intellectual disabilities] [doctoral dissertation, Univerza v Ljubljani, Pedagoška fakulteta]. Repozitorij Univerze v Ljubljani. http://pefprints.pef.uni-lj.si/3973/

Jenko, N., \& Lipec Stopar, M. (2017). Reading literacy of students with intellectual disabilities at the end of a period of systematic literacy development. In S. SekušakGalešev (Ed.), Book of Abstracts of ERFCON 2017 - The 9th International Conference of the Faculty of Education and Rehabilitation Sciences at University of Zagreb (p. 25). Faculty of Education and Rehabilitation Sciences.

Jenko, N., \& Lipec Stopar, M. (2019). Challenges of developing reading literacy of students with mild intellectual disabilities. In V.Žunić-Pavlović, A. Grbović i V. Radovanović (Eds.), Book of abstracts, X Međunarodni naučni skup Specijalna edukacija $i$ rehabilitacija danas (p. 91). Faculty of Special Education and Rehabilitation.

Joseph, L., \& McCachran, M. (2003). Comparison of a word study phonics technique between students with moderate to mild mental retardation and struggling readers without disabilities. Education and Training in Developmental Disabilities, 38(2), 192-199.

Levorato, M. C., Roch, M., \& Beltrame, R. (2009). Text comprehension in Down syndrome: The role of lower and higher level abilities. Clinical Linguistics \& Phonetics, 23(4), 285-300. https://doi.org/10.1080/02699200802673259

Levy, Y. (2011). IQ predicts word decoding skills in populations with intellectual disabilities. Research in Developmental Disabilities, 32(6), 2267-2277. https://doi.org/10.1016/j.ridd.2011.07.043

Lipec Stopar, M. (2005). Taksonomija težav bralnega razumevanja na osnovi latentne strukture branja [Taxonomy of reading comprehension problems based on latent structure of reading] [doktorska disertacija, Univerza v Ljubljani]. Univerza $\mathrm{v}$ Ljubljani, Pedagoška fakulteta Ljubljana.

Lipec Stopar, M., i Jenko, N. (2014). Bralna pismenost učencev z intelektualnimi primanjkljaji [Reading literacy of students with intellectual disabilities]. In T. Devjak (Ed.), Sodobni pedagoški izzivi v teoriji in praksi (str. 187-202). Univerza v Ljubljani, Pedagoška fakulteta.

Loveall, S. J., \& Conners, F. A. (2013). Individuals with intellectual disability can selfteach in reading. American Journal on Intellectual and Developmental Disabilities, 118(2), 108-123. https://doi.org/10.1352/1944-7558-118.2.108

Merrill, E. C., Lookadoo, R., \& Rilea, S. (2003). Memory, language comprehension, and mental retardation. In L. Abbeduto (Ed.), International review of research in mental retardation: Language and communication in mental retardation, (Vol. 27, pp. 151-189). Academic Press. 
Metsala, J. L. (2011). Lexical reorganization and the emergence of phonological awareness. In S. B. Neuman \& D. K. Dickinson (Eds.), Handbook of early literacy research (Vol. 3, pp. 66-84). Guilford.

Mullis, I. V. S., Kennedy, A. M., Martin, M. O., \& Sainsbury, M. (2006). PIRLS 2006 Assessment framework and specifications: Progress in International Reading Literacy Study. International Association for the Evaluation of Educational Achievement.

Novosel, M. (1989). Acadia-test razvoja sposobnosti-priročnik. Fakultet za defektologiju Sveučilišta u Zagrebu.

Pečjak, S. (1999). Osnove psihologije branja. Spiralni model kot oblika razvijanja bralnih sposobnosti učencev [Fundamentals of reading psychology. Spiral model as a form of developing students' reading skills]. Znanstveni inštitut Filozofske fakultete.

Pečjak, S. (2010). Psihološki vidiki bralne pismenosti [Psychological aspects of reading literacy]. Univerza v Ljubljani, Filozofska fakulteta.

Pečjak, S., i Gradišar, A. (2002). Bralne učne strategije [Reading learning strategies]. Zavod RS za šolstvo.

Pečjak, S., Magajna, L,. i Podlesek, A. (2012a). Ocenjevalna shema bralnih zmožnosti učencev 1.-3. razreda-priročnik [Assessment scheme of students' reading abilities 1-3. grade - handbook]. Znanstvena založba Filozofske fakultete.

Pečjak, S., Magajna, L., i Podlesek, A. (2012b). Bralni test-priročnik [Reading test manual]. Znanstvena založba Filozofske fakultete.

Pečjak, S., Magajna, L., i Potočnik, N. (2012c). Ocenjevalna shema bralnih zmožnosti učencev (1., 2., 3. razred) - preizkus [Assessment scheme of students' reading abilities (1st, 2nd, 3rd grade) - test]. Znanstvena založba Filozofske fakultete.

Predmetna kurikularna komisija za slovenščino. (2004). Učni načrt za prilagojen izobraževalni program z nižjim izobrazbenim standardom [Curriculum: adapted educational program with a lower educational standard]. https://www.gov.si/ assets/ministrstva/MIZS/Dokumenti/Izobrazevanje-otrok-s-posebnimi-potrebami/ OS/un_slo_2_dos_pp.pdf

Pogačnik, V. (1995). Pojmovanje inteligentnosti [The concept of intelligence]. Didakta.

Poznanovič Jezeršek, M., Cestnik, M., Čuden, M., Gomivnik Thuma, V., Honzak, M., Križaj Ortar, M., Rosc Leskovec, D., i Žveglič, M. (2011). Učni načrt: program osnovnošolskega izobraževanja. Slovenščina [Curriculum: primary education program. Slovenian]. Zavod RS za šolstvo. http://www.mizs.gov.si/fileadmin/mizs. gov.si/pageuploads/podrocje/os/prenovljeni_UN/UN_slovenscina_OS.pdf

Rathvon, N. (2004). Early Reading Assessment: A practitioner's handbook. Guilford.

Raven, J., Raven, J. C,. \& Court, J. H. (1999). Priročnik za Ravenove progresivne matrice in besedne lestvice: Splošni pregled (1. zvezek) [Manual for Raven's Progressive Matrices and Vocabulary Scales. General Overview (Section 1)]. Center za psihodiagnostična sredstva.

Pravilnik o organizaciji in načinu dela komisij za usmerjanje otrok s posebnimi potrebami [Regulations for the organisation and work of the Commissions], Uradni list RS, št. 88/13 (2013). http://www.pisrs.si/Pis.web/pregledPredpisa?id=PRAV11834

Rosenquist, C., Conners, F. A., \& Roskos-Ewoldsen, B. (2003). Phonological and visuo-spatial working memory in individuals with intellectual disability. American Journal on Mental Retardation, 108(6), 403-413. https://doi.org/10.1352/0895-8017(2003)108<403:PAVW $\mathrm{MI}>2.0 . \mathrm{CO} ; 2$

Saunders, K. J. (2007). Word-attack skills in individuals with mental retardation. Mental Retardation and Developmental Disabilities Research Reviews, 13(1), 78-84. https://doi.org/10.1002/mrdd.20137 
Sermier Dessemontet, R., \& de Chambrier, A. F. (2015). The role of phonological awareness and letter-sound knowledge in the reading development of children with intellectual disabilities. Research in Developmental Disabilities, 41, 1-12. https://doi.org/10.1016/j.ridd.2015.04.001

Soltani, A., \& Roslan, S. (2013). Contributions of phonological awareness, phonological short-term memory, and rapid automated naming, toward decoding ability in students with mild intellectual disability. Research in Developmental Disabilities, 34(3), 1090-1099. https://doi.org/10.1016/j.ridd.2012.12.005

Van Tilborg, A., Segers, E., van Balkom, H., \& Verhoeven, L. (2014). Predictors of early literacy skills in children with intellectual disabilities: A clinical perspective. Research in Developmental Disabilities, 35(7), 1674-1685. https://doi.org/10.1016/j.ridd.2014.03.025

Verhoeven, L., \& Vermeer, A. (2006). Literacy achievement of children with intellectual disabilities and differing linguistic backgrounds. Journal of Intellectual Disability Research, 50(10), 725-738. https://doi.org/10.1111/j.1365-2788.2006.00838.x

Vovk-Ornik, N. (Ed.). (2015). Kriteriji za opredelitev vrste in stopnje primanjkljajev, ovir oz. motenj otrok s posebnimi potrebami [Criteria for defining the type and level of disabilities, obstacles and disorders of children with special needs]. Zavod RS za šolstvo. http://www.zrss.si/pdf/Kriteriji-motenj-otrok-s-posebnimi-potrebami.pdf

Weedon, C., Reed, G., Kovačič, D., Grobler, M., Košak Babuder, M., Lipec Stopar, M., Magajna, L. Ozbič, M., Pulec Lah S., Brajovič, T., Trstenjak, M., Boben, D., Hudoklin, M., i Kogovšek, D. (2009). Profil ocene posebnih potreb: Priročnik za uporabo. Računalniško podprt diagnostični preizkus z izdelavo profila: 5-14 let [Special Needs Assessment Profile: User Manual. Computer-aided diagnostic test with profile production: 5-14 years]. Center za psihodiagnostična sredstva.

Wren, S. (2001). The cognitive foundations of learning to read: A framework. Southwest Educational Development Laboratory. https://www.sedl.org/reading/framework/ framework.pdf

Zakon o usmerjanju otrok s posebnimi potrebami - ZUOPP-1 [Placement of Children with Special Needs Act], Uradni list RS, št. 58/11, 40/12 (2012).

http://pisrs.si/Pis.web/pregledPredpisa?id=ZAKO5896

\title{
Čitalačka pismenost učenika sa intelektualnom ometenošću na kraju perioda sistematskog razvoja pismenosti
}

\author{
Nika Jenko, Mojca L. Lipec Stopar \\ Univerzitet u Ljubljani, Pedagoški fakultet, Ljubljana, Slovenija
}

Razvoj čitanja kod učenika s lakom intelektualnom ometenošću (IO) predstavlja veliki izazov za njihove nastavnike. U Sloveniji ovi učenici obično pohađaju prilagođeni nastavni program sa nižim obrazovnim standardima, koji predviđa da će učenici do kraja perioda sistematskog podučavanja čitanja savladati tehniku čitanja do nivoa, koji će im omogućiti da se primarno fokusiraju na razumevanje teksta. Cilj istraživanja bio je utvrđivanje u kojoj meri je taj cilj ispunjen u grupi od 61 učenika petog razreda, koji pohađaju prilagođeni program sa nižim obrazovnim standardima, na kraju perioda 
sistematskog razvoja pismenosti. Pomoću faktorske analize proučavali smo karakteristike čitalačke pismenosti kod ove grupe učenika. Pored toga, uporedili smo rezultate učenika s IO sa normama na kraju perioda sistematskog razvoja pismenosti učenika tipičnog razvoja (treći razred). Zaključeno je, da se efikasnost čitanja učenika s lakom IO na kraju perioda sistematskog razvoja pismenosti i dalje zasniva na procesima nižeg nivoa (dekodiranje). Teškoće u čitanju učenika s IO su složene i posledica su različitih faktora čitanja. Uzimajući u obzir tačnost usmenog čitanja učenika, zaključeno je, da samo manji procenat učenika postigne očekivani kurikularni standard čitanja. Na osnovu rezultata dato je nekoliko metodičkih i drugih smernica za planiranje nastave čitanja.

Ključne reči: čitalačka pismenost, razvoj pismenosti, intelektualna ometenost, prilagođeni program sa nižim obrazovnim standardom 
READING LITERACY AND INTELLECTUAL DISABILITIES

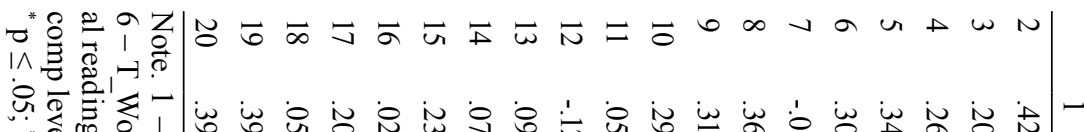
*

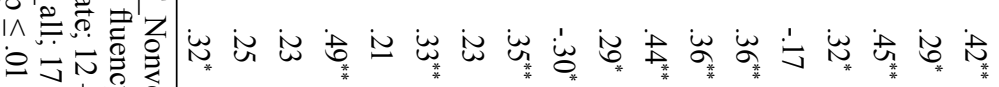

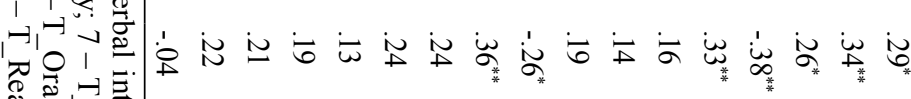

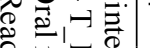

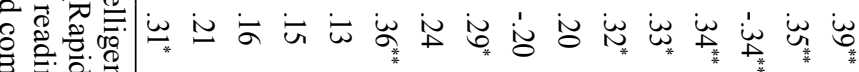

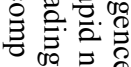

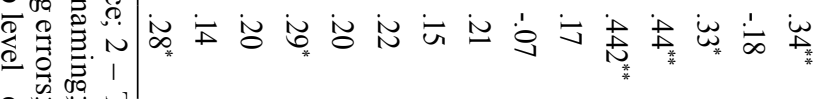

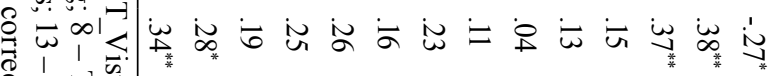

要,

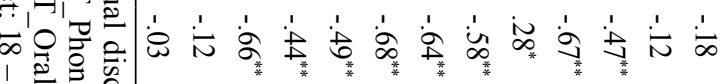

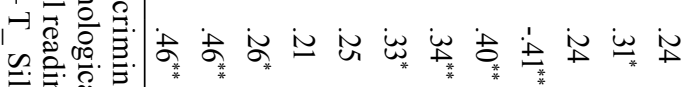

垈:

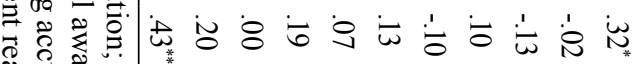

䓂产

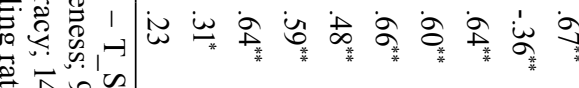

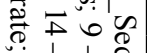

6,

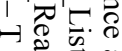

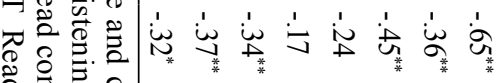

을

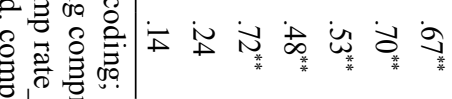

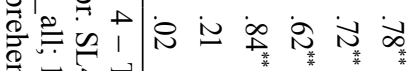

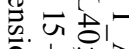

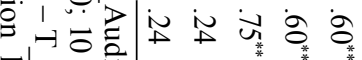

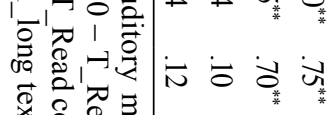

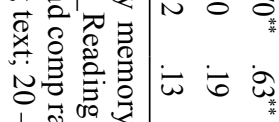

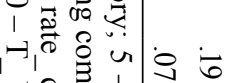

ऽ융

迥峿

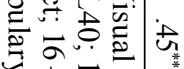

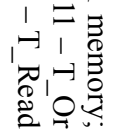

